\title{
PENERAPAN MEDIA PEMBELAJARAN INTERAKTIF MATEMATIKA BERBASIS MACROMEDIA FLASH 8 PADA SISWA KELAS VIII SMP NEGERI 2 ADIPALA
}

\author{
Pradhesta Dhaneswara \\ Universitas Negeri Semarang \\ dhee.bats@gmail.com
}

\begin{abstract}
ABSTRAK
Tujuan penelitian ini untuk mengetahui perbedaan dan peningkatan hasil belajar pada siswa yang dibelajarkan menggunakan media pembelajaran interaktif Flash. Desain penelitian yang digunakan dalam penelitian ini adalah quasi experimental design. Populasi dalam penelitian ini yaitu siswa SMP Negeri 2 Adipala. Sampel dalam penelitian diambil menggunakan teknik sampling jenuh dengan dipastikan kesetaraannya (matching) sehingga diperoleh siswa kelas VIII A (kelompok eksperimen) dan siswa kelas VIII B (kelompok kontrol). Teknik analisis data yang digunakan yaitu uji prasyarat analisis meliputi uji normalitas dan homogenitas, dan uji hipotesis meliputi uji beda dan uji gain. Hasil penelitian dengan analisis statistik uji-t menunjukkan bahwa terdapat perbedaan yang signifikan hasil belajar siswa yang pembelajaran dengan menggunakan media pembelajaran interaktif Flash dengan hasil belajar siswa yang pembelajaran tidak menggunakan media pembelajaran interaktif $F$ lash. Dibuktikan dengan $t_{\text {hitung }}>t_{\text {tabel }}(3,457>2,001)$. Berdasarkan analisis uji gain menunjukkan bahwa terdapat peningkatan hasil belajar yang lebih tinggi pada siswa yang dibelajarkan dengan menggunakan media pembelajaran interaktif Flash dibandingkan dengan hasil belajar siswa yang dibelajarkan tidak menggunakan media pembelajaran interaktif Flash. Dibuktikan dari nilai pretest dan posttest didapat rata-rata skor gain kelompok eksperimen lebih tinggi yakni 0,498 sedangkan kelompok kontrol adalah 0,298.
\end{abstract}

Kata Kunci: media pembelajaran interaktif, hasil belajar, flash.

\begin{abstract}
The purpose of this study was to determine the differences and improvement of learning outcomes in students who were taught using Flash interactive learning media. The research design used in this study is quasi experimental design. The population in this study is students of SMP Negeri 2 Adipala. The sample in the study was taken using a sampling technique saturated with ascertained equality (matching) so that the students of class VIII A (experimental group) and students of class VIII B (control group) were obtained. The data analysis technique used is the analysis prerequisite test including normality and homogeneity tests, and hypothesis testing includes different test and gain test. The results of the study with the t-test statistical analysis showed that there were significant differences in learning outcomes of students learning by using Flash interactive learning media with learning outcomes of students whose learning did not use Flash interactive learning media. It is proven by $t_{\text {hitung }}>t_{\text {tabel }}(3,457>2,001)$. Based on the analysis of the gain test shows that there is a higher increase in learning outcomes for students who are taught using Flash interactive learning media compared to the learning outcomes of students who are taught not to use Flash interactive learning media. As evidenced by the pretest and posttest scores, the average gain score of the experimental group is higher, which is 0.498 while the control group is 0.298 .
\end{abstract}

Keyword: interactive learning media, learning outcomes, flash. 


\section{PENDAHULUAN}

Perkembangan IImu Pengetahuan dan Teknologi (IPTEK) menuntut peningkatan kualitas Sumber Daya Manusia (SDM). Pendidikan sebagai upaya untuk mencerdaskan kehidupan bangsa secara terus menerus melakukan pengembangan dalam sistem pelaksanaanya, salah satunya adalah dengan menerapkan pengembangan media. Proses belajar mengajar akan lebih efektif dan efisien apabila ditunjang dengan penggunaan media yang memadai. Menurut Roestiyah N.K. (1986:60) media adalah sarana pengajaran pendidikan yang fungsinya dapat digunakan untuk membantu tercapainya suatu tujuan.

Dalam dunia pendidikan, perkembangan teknologi dan informasi membawa dampak positif. Dengan adanya perkembangan teknologi informasi, dunia pendidikan menjadi lebih baik, hal itu ditandai adanya inovasi dalam penggunaan media pembelajaran dalam dunia pendidikan. Penggunaan media pembelajaran yang tepat dapat memberi manfaat bagi peserta didik. Ketertarikan untuk memahami suatu materi menggunakan media pembelajaran dapat membantu peserta didik untuk menguasai materi tersebut.

Berdasarkan hasil wawancara dengan guru mata pelajaran Matematika, bahwa dalam penerimaan materi pelajaran di sekolah, siswa maupun guru banyak terjadi kendala. Penyebab kendala tersebut diantaranya yaitu pembelajaran yang masih menggunakan metode ceramah dan media menggunakan gambar sehingga siswa hanya mendengarkan, mencatat dan menjawab apabila ditanya oleh guru dan tidak berperan aktif dalam proses pembelajaran.

Menurut Arsyad (2011: 15) dalam suatu proses belajar mengajar dua unsur yang amat penting adalah metode mengajar dan media pembelajaran. Pemilihan model pembelajaran yang inovasi merupakan bentuk kreativitas guru dalam mengelola pembelajaran yang semula monoton, membosankan, menjenuhkan menuju pembelajaran yang aktif dan efektif. Dalam pembelajaran, media memegang peranan penting dalam mencapai sebuah tujuan belajar. Hubungan komunikasi antara guru dan siswa akan lebih baik dan efisien jika menggunakan media.

Media pembelajaran yang menarik, dapat menjadikan siswa lebih giat dalam menumbuhkan rasa keingintahuan dan berpikir kritis serta aktif dalam pembelajaran. Oleh karena itu, peneliti menggunakan pembelajaran berbasis media yang diharapkan mampu menumbuhkan siswa menjadi aktif dalam pembelajaran. Dalam proses pembelajaran keterbatasan guru dalam mengajar di sekolah membuat guru tidak bisa mengajari siswa karena keterbatasan waktu. Dengan adanya media ini, diharapkan siswa lebih aktif belajar dan membantu siswa yang belum paham tentang materi yang telah diajarkan di sekolah

Berdasarkan penelitian yang dilakukan oleh Reza Pramono (2013) menjelaskan bahwa secara umum media pembelajaran dapat disimpulkan sebagai suatu perangkat pembelajaran yang membantu pengajar menyampaikan isi materi ke peserta didik sehingga dapat meningkatkan kualitas proses pembelajaran. Melalui penggunaan media pembelajaran diharapkan dapat meningkatkan kualitas proses belajar mengajar yang pada akhirnya dapat mempengaruhi kualitas hasil belajar siswa.

Memperhatikan alasan diatas, maka penulis berinisiatif untuk membuat sebuah media pembelajaran yang berbasis multimedia yaitu media pembelajaran Flash untuk mata pelajaran Matematika khususnya pada pokok bahasan Bangun Ruang Sisi Datar. Mata pelajaran Matematika merupakan mata pelajaran yang penting karena merupakan dasar dari banyak mata pelajaran lain.

Berdasarkan hasil observasi yang sudah dilakukan di SMP Negeri 2 Adipala, diketahui bahwa pembelajaran belum menggunakan media pembelajaran interaktif. Model pembelajaran yang digunakan yaitu ceramah dengan guru sebagai sumber utama pembelajaran. Siswa hanya mendengarkan, mencatat, dan menjawab hanya jika ditanya oleh guru dan kurang aktif dalam proses pembelajaran. Tidak adanya timbal balik dari siswa 
membuat guru kurang mengetahui kemampuan dan potensi siswa.

\section{METODE}

Metode yang digunakan dalam penelitian ini yaitu penelitian eksperimen. Desain penelitian eksperimen yang digunakan yaitu quasi experimental bentuk nonequivalent control group design. Dalam desain ini terdapat dua kelas sebagai subjek penelitian, yaitu kelas eksperimen dan kontrol. Kelas eksperimen diberikan perlakuan menggunakan media pembelajaran interaktif Flash. Sedangkan, kelas kontrol tidak diberikan perlakuan (pembelajaran konvensional). Perilaku kelas eksperimen dan kontrol diukur menggunakan tes awal (pretest) untuk mengetahui kemampuan asal sebelum dibelajarkan, dan tes akhir (posttest) untuk mengetahui keadaan akhir berupa hasil belajar setelah dibelajarkan.

Populasi dalam penelitian ini yaitu siswa SMP Negeri 2 Adipala. Sampel dalam penelitian diambil menggunakan teknik sampling jenuh dengan dipastikan kesetaraannya (matching) sehingga diperoleh siswa kelas VIII A (kelompok eksperimen) sebanyak 33 orang dan siswa kelas VIII B (kelompok kontrol) sebanyak 32 orang.

Variabel yang akan diukur dalam penelitian ini yaitu perbedaan dan peningkatan hasil belajar siswa setelah dibelajarakan menggunakan media pembelajaran interaktif Flash. Teknik pengumpulan data dalam penelitian ini meliputi teknik wawancara, dokumentasi, observasi, dan tes. Penelitian yang digunakan berupa instrumen soal tes, dan lembar instrumen keaktifan siswa. Pengujian validitas soal tes menggunakan analisis korelasi pearson pada bivariate correlations. Pengujian reliabilitas soal tes menggunakan rumus KR-21, dengan kriteria pengujian: jika $r_{\text {hitung }}>r_{\text {tabel, maka semua butir soal }}$ dinyatakan reliabel. Rumus yang digunakan yaitu:

$$
r_{i}=\frac{k}{(k-1)}\left\{1-\frac{M(k-m)}{k s_{t}^{2}}\right\}
$$

Keterangan:

$\mathrm{k}$ : jumlah item dalam instrumen

$M$ : mean skor total

$S_{t}^{2}:$ varians total

Teknik analisis data hasil penelitian menggunakan uji prasyarat analisis dan uji hipotesis. Uji prasyarat analisis diperlukan untuk mengetahui apakah analisis data untuk pengujian hipotesis dapat dilanjutkan atau tidak. Uji prasyarat yang digunakan dalam penelitian ini yaitu uji normalitas dan homogenitas. Untuk menguji normalitas, peneliti menggunakan uji lilliefors dengan melihat nilai pada kolom kolmogorovsmirnov. Uji homogenitas pada penelitian ini menggunakan program SPSS versi 23 dengan taraf signifikansi 0,05.

Uji hipotesis dilakukan untuk membedakan apakah hasil belajar dan keaktifan antara siswa kelompok eksperimen dan kontrol sama atau berbeda setelah memperoleh perlakuan. Uji hipotesis dalam penelitian ini menggunakan uji dua pihak (two tailed) metode independent sample t-test pada program SPSS versi 23. Setelah data dinyatakan berbeda dapat dikatakan bahwa penelitian ini telah mencapai hasil yang dinginkan.

\section{HASIL DAN PEMBAHASAN}

Hasil penelitian berupa data hasil belajar siswa selama penelitian berlangsung. Data tersebut berasal dari data hasil belajar siswa yang diukur sebelum dan setelah dibelajarkan menggunakan media pembelajaran interaktif Flash. Penilaian hasil belajar siswa dalam pembelajaran Matematika bangun ruang sisi datar berdasarkan pada instrumen soal tes. Soal tes yang digunakan berisi 40 butir soal dengan 4 pilihan jawaban. Soal tes yang digunakan sudah teruji validitas dan 
reliabilitasnya. Selain teruji validitas dan reliabilitasnya, soal-soal tersebut juga mempunyai daya pembeda soal (minimal cukup). Hasil belajar siswa diambil dari jumlah skor total yang diperoleh, dibandingkan dengan skor maksimal yaitu 100 , kemudian dikalikan 100. Penilaian hasil belajar siswa kelompok eksperimen dan kontrol dilakukan sebelum dan setelah dibelajarkan. Nilai rata-rata tes awal (pretest) siswa kelas eksperimen yaitu 62,919 . Nilai tertinggi dari nilai pretest siswa kelompok eksperimen yaitu 82 dan nilai terendahnya 44 . Sementara, nilai rata-rata tes awal (pretest) kelompok control 60,875. Nilai tertinggi dari nilai pretest siswa kelompok kontrol 82 dan nilai terendahnya 46.

Setelah diberi perlakuan, nilai rata-rata tes akhir (posttest) siswa kelompok eksperimen 81,404 . Nilai tertinggi hasil belajar siswa kelompok eksperimen yaitu 98 dan nilai terendahnya 64 . Sementara, nilai rata-rata tes akhir (posttest) siswa kelompok kontrol 72,562. Nilai tertinggi hasil belajar siswa kelompok kontrol yaitu 90 dan nilai terendahnya 48. Deskripsi data hasil belajar siswa berdasarkan hasil tes awal (pretest) dan tes akhir (posttest) dapat dibaca pada tabel 1.

\section{Tabel 1.}

\section{Rekapitulasi Data Hasil Belajar Siswa}

\begin{tabular}{|c|l|l|l|l|l|}
\hline \multirow{2}{*}{ No } & \multirow{2}{*}{ Kriteria } & \multicolumn{2}{c|}{ Tes Awal (Pretest) } & \multicolumn{2}{c|}{ Tes Akhir (Posttest) } \\
\cline { 3 - 6 } & $\begin{array}{c}\text { Kelompok } \\
\text { Eksperimen }\end{array}$ & $\begin{array}{c}\text { Kelompok } \\
\text { Kontrol }\end{array}$ & $\begin{array}{c}\text { Kelompok } \\
\text { Eksperimen }\end{array}$ & $\begin{array}{c}\text { Kelompok } \\
\text { Kontrol }\end{array}$ \\
\hline 1 & Jumlah Siswa & 33 & 32 & 33 & 32 \\
2 & Rata-rata (Mean) & 62,919 & 60,875 & 81,404 & 72,562 \\
3 & Median & 64 & 58 & 82 & 72 \\
4 & Standar Deviasi & 10,867 & 9,888 & 8,821 & 11,708 \\
5 & Varian & 118,097 & 97,790 & 77,817 & 137,092 \\
7 & Rentang & 42 & 36 & 34 & 42 \\
8 & Nilai Tertinggi & 82 & 82 & 98 & 90 \\
\hline
\end{tabular}

Berdasarkan tes awal (pretest) dan tes akhir (posttest) yang diberikan kepada siswa di kelompok eksperimen dan kontrol, diperoleh rekap data hasil belajar siswa pada tabel 1. Berdasarkan tabel 1, diketahui bahwa nilai rata-rata kemampuan awal (pretest) kelompok eksperimen 62,919 dan kelompok kontrol 60,875 . Selisih antara kedua rata-rata tersebut 2,004. Dilihat dari selisih rata-rata kemampuan awal tersebut, dapat dikatakan bahwa tidak terdapat perbedaan nilai yang signifikan sebelum dibelajarkan. Sedangkan nilai rata-rata hasil belajar (posttest) kelompok eksperimen 81,404 dan kelompok kontrol 72,562. Selisih antara kedua rata-rata tersebut 8,842 . Dilihat dari selisih rata-rata hasil belajar tersebut, dapat dikatakan bahwa terdapat perbedaan nilai yang signifikan setelah dibelajarkan menggunakan media pembelajaran interaktif Flash.

Tujuan penelitian ini untuk mengetahui perbedaan dan peningkatan hasil belajar pada siswa yang dibelajarkan menggunakan media pembelajaran interaktif Flash.

Berdasarkan hasil penelitian, terdapat perbedaan yang signifikan antara hasil belajar siswa yang di belajarakan dengan media pembelajaran interaktif Flash dan siswa yang dibelajarkan dengan model ceramah. Hal tersebut dibuktikan dengan nilai rata-rata posttest hasil belajar siswa kelas eksperimen yaitu 81,404 sedangkan kelompok kontrol yaitu 72,562 .

Berdasarkan uji gain diketahui kelompok kontrol memiliki indeks gain 0,298 dengan kategori rendah. Sementara itu indeks gain kelompok eksperimen yakni 0,498 dengan kategori sedang. Sehingga dapat disimpulkan bahwa kelompok eksperimen memiliki peningkatan hasil belajar yang lebih tinggi dibandingkan dengan kelompok kontrol.

Uji hipotesis perbedaan hasil belajar dan keaktifan siswa dalam penelitian ini menggunakan uji dua pihak (two tailed) metode independent samples t-test pada SPSS versi 23. Berdasarkan hasil penghitungan, diperoleh $t_{\text {hitung }}$ sebesar 3,457 . $t_{\text {tabel }}$ untuk uji dua pihak dengan $\mathrm{dk}=$ 63 dan taraf signifikansi 0,05, sebesar 2,001. Hasil penghitungan analisis statistik uji t, menunjukkan bahwa $t_{\text {hitung }}>t_{\text {tabel }}(3,457>$ 
$2,001)$ dan signifikansi $<0,05(0,001<0,05)$. Berdasarkan hasil penghitungan tersebut, maka $\mathrm{H}_{0}$ ditolak sehingga $\mathrm{H}_{\mathrm{a}}$ diterima. Jadi, dapat disimpulkan bahwa terdapat perbedaan yang signifikan antara siswa yang dibelajarkan menggunakan media pembelajaran interaktif Flash dan siswa yang dibelajarkan dengan model ceramah.

\section{SIMPULAN}

Berdasarkan hasil penelitian dan pembahasan dapat diambil simpulan sebagai berikut:

1. Terdapat perbedaan peningkatan nilai yang signifikan setelah dibelajarkan menggunakan media pembelajaran interaktif Flash. Hal tersebut dibuktikan dari nilai rata-rata posttest hasil belajar siswa kelompok eksperimen yaitu 81,404 dan kelompok kontrol yaitu 72,562 .

2. Terdapat pengaruh peningkatan hasil belajar yang lebih tinggi pada siswa yang dibelajarkan dengan media pembelajaran interaktif Flash dibandingkan dengan hasil belajar siswa yang dibelajarkan dengan model pembelajaran ceramah. Hal tersebut dapat dibuktikan dengan skor gain kelas eksperimen yaitu 0,498 sedangkan skor gain kelas kontrol 0,298.

\section{DAFTAR PUSTAKA}

Arikunto, Suharsimi. 2010. Prosedur Penelitian Suatu Pendekatan Praktik. Jakarta: Rineka Cipta

Arsyad, Azhar. 2009. Media Pembelajaran. Jakarta: Raja Grafindo Persada.

Poerwanti, Endang. 2008. Bahan Ajar Cetak Assesmen Pembelajaran SD. Jakarta: Direktorat Jenderal Pendidikan Tinggi Departemen Pendidikan Nasional.
Pramono, Reza. 2013. Penerapan Media Pembelajaran Berbasis Macromedia Flash 8 Meningkatkan Hasil Belajar Siswa Mata Pelajaran Alat Ukur Kelas X TPM SMK Taman Siswa

Surabaya.http://ejournal.unesa.ac.i $\mathrm{d} /$ index.php/jurnalpendidikanteknik mesin/article/view/6545/bacaartikel, [diakses, 2 September 2017]

Pressman, Roger S. 2010. Software Engineering: A Practitioner's Approach. 7th Edition. New York: McGraw-Hill Book Company.

Priyatno, Duwi. 2010. Paham Analisa Statistik Data dengan SPSS. Yogyakarta: Media Kom.

Sudjana, Nana dan Ahmad Rivai. 1991. Media Pengajaran. Bandung: Sinar Baru.

Sudjana, Nana. 2011. Penilaian Hasil Proses Belajar Mengajar. Bandung: PT. Remaja Rosdakarya.

Sugiyono. 2013. Metode Penelitian Kuantitatif, Kualitatif dan $R$ \& D. Bandung: Alfabeta. 